\title{
The Effect of Active Paper Packaging Enriched with Oleoresin from Solid Waste of Pressed Curcuma xanthorrhiza Roxb. Placement Methods on Quality of Refrigerated Strawberry (Fragaria $x$ ananassa)
}

\author{
Rohula Utami*, Kawiji, Windi Atmaka, Lulus Nurmaya, Lia Umi Khasanah and Godras Jati Manuhara \\ Department of Food Science and Technology, Faculty of Agriculture, \\ Universitas Sebelas Maret, Surakarta, Indonesia \\ *Corresponding author: rohulautami@staff.uns.ac.id
}

\begin{abstract}
Strawberry is a popular and nutritious fruit. However, its improper post-harvest handling leads to quality degradation. The aim of this study was to investigate the effects of active paper packaging placements methods on strawberry (Fragaria $x$ ananassa) quality during refrigerated storage. Strawberry quality was determined based on the physical (weight loss, hardness, color), chemical ( $\mathrm{pH}$, total titratable acid, total soluble solids and vitamin C content) and microbiological (total plate count) properties. The results of this study indicated that different placement methods of active paper packaging had no significant effect on the physical and chemical qualities; but it did affect the microbiological quality of the strawberries. At the end of the experiment (12 days), the microbial content of $C$ (the bottom and walls), D (covering all surfaces) and $\mathrm{E}$ (cut into pieces) samples were significantly lower than the A (without active paper packaging) and B (the bottom) samples. The Total Plate Count (TPC) values of the control and B samples were higher than the maximum acceptable limit of $6 \log 10$ colony-forming units (CFU) $\mathrm{g}^{-1}$, while the other samples remained below the limit. These results indicated that a larger surface area of active paper that had contact with the strawberries provided better protection against microbes. Due to their microbial properties, C, D and E treatments maintained the strawberry quality for up to 12 days, compared with 9 days for control and B treatments. Active paper packaging containing oleoresin from solid waste of pressed Curcuma xanthorrhiza Roxb. can be applied to extend the shelf life of strawberries during refrigerated storage.
\end{abstract}

Keywords: active paper packaging; Curcuma xanthorrhiza Roxb.; food quality; refrigerated storage; strawberry

Cite this as: Utami, R., Kawiji, Atmaka, W., Nurmaya, L., Khasanah, L. U., \& Manuhara, G. J. (2021). The Effect of Active Paper Packaging Enriched with Oleoresin from Solid Waste of Pressed Curcuma xanthorrhiza Roxb. Placement Methods on Quality of Refrigerated Strawberry (Fragaria x ananassa). Caraka Tani: Journal of Sustainable Agriculture, 36(1), 155-164. doi: http://dx.doi.org/10.20961/carakatani.v36i1.43027

\section{INTRODUCTION}

Strawberry (Fragaria $x$ ananassa) is a popular fruit commodity in subtropical regions and tropical regions such as Indonesia. Strawberry production continues to increase in response to increased demand. Globally, the production of strawberry gradually increased from 8,069,134 tons in 2017 to $8,337,099$ tons in 2018 (FAO, 2020). In Indonesia, during 2014-2019 the production of strawberry varied from 7,501 tons to 58,884 tons (BPS - Statistics Indonesia, 2020). Strawberry fruit is a horticultural commodity with high nutritional value. According to USDA (2017), strawberry has a fairly complete nutritional content, with each berry containing up

\footnotetext{
* Received for publication July 17, 2020

Accepted after corrections January 5, 2021
} 
to 32 calories, $0.67 \mathrm{~g}$ of protein, $0.30 \mathrm{~g}$ of fat, 7.68 $\mathrm{g}$ of carbohydrate, $2.0 \mathrm{~g}$ of fiber, $16 \mathrm{mg}$ of calcium, $24 \mathrm{mg}$ of phosphorus, $153 \mathrm{mg}$ of potassium, $12 \mathrm{IU}$ of vitamin $\mathrm{A}, 0.024 \mathrm{mg}$ of vitamin $\mathrm{B} 1,58.8 \mathrm{mg}$ of vitamin $\mathrm{C}$ and $90.95 \mathrm{~g}$ of water. Strawberry also shows strong antioxidant capacity related to its phenolic compounds and flavonoids content (Skrovankova et al., 2015).

Improper post-harvest handling of strawberry leads to quality degradation, including poor appearance, weight loss and decreased nutritional value. During storage, strawberries are susceptible to microbial damage which is caused by mold and bacteria. Pathogenic molds infecting strawberries include Botrytis cinerea, which causes gray patches, Colletotrichum acutatum, which causes anthracnose fouling and Phytophthora cactorum, which causes rotting of the fruit skin. Bacteria which cause soft rot in strawberries include Erwinia carotovora, Pseudomonas marginalis and species from the genus Weeksella (Yuliasari et al., 2015). Strawberry damage in the form of soft and watery rotting with brown stains is caused by Rhizopus stolonifer and Mucor piriformis (Siefkes-Boer et al., 2009). These conditions could increase the post-harvest losses due to deterioration, loss of quality, loss of nutritional value, loss of viability and finally commercial loss (Sawicka, 2019). Therefore, the reduction of postharvest losses may become a central pillar of sustainable global food systems (Kikulwe et al., 2018).

Post-harvest losses of strawberry during storage can be inhibited by proper packaging. Packaging can also improve the appearance of the product and prevent products from contaminations (Qanytah and Ambarsari, 2011). Strawberries are usually packaged in mica polyethylene (PET) punnets coated with paper at the bottom side of the packaging. The purpose of the paper is to prevent friction between the fruits and its packaging and ensure that physical damage is minimized. Additional antimicrobial compounds can be added to the paper to improve the functionality of the paper packaging. This active packaging actively changes the condition of the packaged food, prolongs the product's shelflife, enhances the safety of food and maintain food taste and quality (Rodríguez et al., 2008).

Spices and their components, such as oleoresin and essential oils, are commonly used as additive compounds on active packaging. Brody et al.
(2008) mentioned that natural compounds from spices extract, for example cinnamon, thyme, rosemary and oregano showed antimicrobial activity. Combination of paper packaging with several herbs and spices components have been done in the past, for example, the combination of paper packaging with oleoresin extracted from ginger (Wiastuti et al., 2016), oleoresin extracted from cinnamon (Kusuma, 2016) and also oleoresin extracted from curcuma/ Curcuma xanthorrhiza Roxb. (Atmaka et al., 2016).

Curcuma (Curcuma xanthorrhiza Roxb.) contains starch, curcuminoid and essential oil (3-12\%). Hydroxyl phenolate in its curcuminoid produces its antibacterial activity. Curcuma xanthorrhiza essential oil usually contains xanthorrhizol; besides, it usually contains ar-turmerone which has insect repellent activity (Adipratama, 2009). Xanthorrhizol isolated from the ethanol extract of Curcuma xanthorrhiza Roxb. reported have antibacterial activity against foodborne pathogens such as Bacillus cereus, Clostridium perfringens, Listeria monocytogenes, Staphylococcus aureus, Salmonella typhimurium and Vibrio parahaemolyticus (Lee et al., 2008). Diastuti et al. (2019) also mentioned that acetone extract and chloroform fraction of C. xanthorrhiza shown antifungal activities against A. fumigatus, Epidermophyton $s p$, Penicillium sp and T. rubrum.

Curcuma is commonly used as herbal drink material by pressing and separating the aqueous and solid parts. Only the aqueous part of curcuma is then processed into curcuma drink, while the solid part is usually thrown away as waste. However, the solid waste of curcuma still contains curcumin (0.031-0.044\%) and essential oils (0.12-0.15\%), which have antimicrobial and antioxidant properties (Wibowo, 2003). Because of that, Atmaka et al. (2016) enriched active paper with oleoresin extracted from the solid waste curcuma and reported that the $4 \%$ oleoresin was needed to increase the inhibition zone of Aspergillus niger growth. Another study also showed that $1.25-2.5 \%$ of eugenol from clove on hydrophobic starch solution could inhibit the growth of pathogenic bacteria, including Escherichia coli, Bacillus cereus and Staphylococcus aureus (Vanit et al., 2010). Meanwhile, the use of active packaging incorporated with cinnamon essential oil could inhibit the browning of mushrooms (Echegoyen and Nerín, 2015). However, the use of active 
paper packaging enriched with oleoresin from pressed curcuma waste on strawberry has never been studied before.

Commonly, strawberries are packed on the punnet with paper placed on the bottom part. Echegoyen and Nerín (2015) mentioned that a larger surface area of active paper that has contact with the fruits could increase the antimicrobial properties. Hence, the purpose of this study was to investigate the effect of active paper packaging placement methods on strawberry quality, including its physical, chemical and microbial qualities, by measuring the weight loss, color change, hardness, $\mathrm{pH}$ value, total titratable acids (TTA), vitamin C content, total dissolved solids and the presence of microorganisms by using Total Plate Count (TPC) during refrigerated storage.

\section{MATERIALS AND METHOD}

\section{Preparation of strawberries}

Fresh strawberries were obtained from Andi Stroberi (strawberry farm at Tawangmangu, Karanganyar, Indonesia). Strawberries were collected in boxes and transported to the laboratory prior to the sorting and cleaning with dry tissue papers.

\section{Preparation of active paper packaging}

Active paper was prepared from $15 \mathrm{~g}$ of paper pulp immersed in $250 \mathrm{~mL}$ distilled water for 24 hours. Then, $250 \mathrm{~mL}$ water was added and mixed

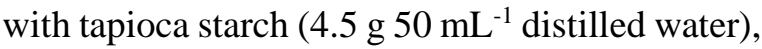
chitosan in $1 \%$ glacial acetic acid $\left(0.45 \mathrm{~g} 100 \mathrm{~mL}^{-}\right.$ ${ }^{1}$ ) and $4 \%$ (w/w of paper pulp) oleoresin extracted from the solid waste of pressed Curcuma xanthorrhiza Roxb. (Atmaka et al., 2016). The ingredients were mixed, molded and dried to form active paper (Manuhara et al., 2016).

\section{Application of active paper packaging}

The covers of the mica PET punnets were perforated with 4 holes of $0.6 \mathrm{~cm}$ diameter spaced $1.5 \mathrm{~cm}$ apart (Echegoyen and Nerín, 2015). The active papers $\left(213 \pm 1 \mathrm{~cm}^{2}\right)$ were placed in the mica PET punnets with various methods. Mica without active paper packaging (A) was used as the control and active paper was evaluated with four different placements: on the bottom (B), on the bottom and walls $(\mathrm{C})$, covering all surfaces (D) and cut into pieces then placed on the sidelines of strawberries (E). Three active papers $(7 \mathrm{~cm} \mathrm{x}$ $10.2 \mathrm{~cm}$ ) were prepared for B samples and placed on the bottom of mica PET punnets. For $\mathrm{C}$ treatment, two pieces of $9.5 \mathrm{~cm} \times 6.5 \mathrm{~cm}$ active paper were placed on the bottom side while two pieces of $9.5 \mathrm{~cm} \times 2.8 \mathrm{~cm}$ and two pieces of $6.5 \mathrm{~cm} \times 2.8 \mathrm{~cm}$ active paper were placed on three walls side of punnets. Six pieces of active paper covered all punnet by placing $9.5 \mathrm{~cm} \times 6.5 \mathrm{~cm}$ on the top and bottom, $9.5 \mathrm{~cm} \mathrm{x} 2.8 \mathrm{~cm}$ or $6.5 \mathrm{~cm}$ $\mathrm{x} 2.8 \mathrm{~cm}$ on all part of walls to prepare D samples. The active papers $\left(213 \mathrm{~cm}^{2}\right)$ were cut into little pieces of $2 \mathrm{~mm}$ x $20 \mathrm{~mm}$ size and placed between the strawberries for $\mathrm{E}$ treatment samples. Strawberries $(7$ pieces $)$ were placed in each punnets and stored for 12 days at $10 \pm 2^{\circ} \mathrm{C}$. They were analyzed on day $0,3,6,9$ and 12 to evaluate the quality of strawberries.

\section{Physical analysis}

Physical analyses were performed to evaluate changes in strawberry quality in terms of weight loss, hardness and skin color. Weight loss was analyzed by using gravimetric method (Nasution et al., 2012). Skin color was analyzed using a PCE-RGB (red, green, blue) color analyzer (Lutron Electronic) with a white calibration value of 1,023 for all three indicators. Hardness was analyzed with a FR-5105 fruit hardness tester (Lutron Electronic).

\section{Chemical analysis}

Chemical analyses were performed to evaluate changes in strawberry quality including vitamin $\mathrm{C}$ content, $\mathrm{pH}$ value, TTA and total soluble solids. A Checker pH Tester-H198103 (Hanna Instruments) was used to measure the $\mathrm{pH}$ after sample homogenization in an equal amount of distilled water (AOAC, 1995). Total soluble solid was measured by using an ATAGO hand refractometer. Vitamin $\mathrm{C}$ content was analyzed by iodometric titration (Sudarmadji, 2010). TTA was analyzed by titration method, using phenolphthalein as an indicator and $0.1 \mathrm{~N}$ of $\mathrm{NaOH}$ as a titrant (Sudarmadji, 2010).

\section{Microbiological analysis}

Microbiological analysis was performed to evaluate changes in strawberry quality by the TPC test. Nogales-Delgado et al. (2013) mentioned that due to Regulation E.C. (No. 2073/2005), the end of the shelf-life from the microbiological point of view, set at $6 \log$ colony-forming units (CFU) $\mathrm{g}^{-1}$ for total aerobic count mesophiles or TPC values. TPC values were determined by analyzing $10 \mathrm{~g}$ samples of aseptically minced strawberries, 
which were homogenized in $90 \mathrm{~mL}$ of sterilized $0.85 \% \mathrm{NaCl}$ saline water. After serial dilution in the same saline solution $(9 \mathrm{~mL}), 1 \mathrm{~mL}$ of each diluted sample was plated on plate count agar (PCA; Merck) in duplicate. The inoculated plates were incubated at $37^{\circ} \mathrm{C}$ for 2 days. TPC was expressed as $\log 10 \mathrm{CFU} \mathrm{g}^{-1}$ (Fardiaz, 1993).

\section{Statistical analysis}

The research was designed to evaluate the effect of active papers placement method on strawberries quality by packaged strawberries at different treatments (A-E) and each experiment was replicated twice. Data were subjected to

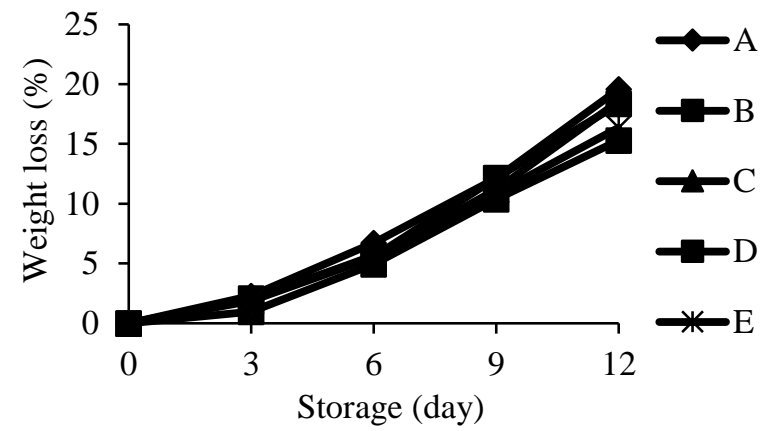

Physical parameters (Weight loss)

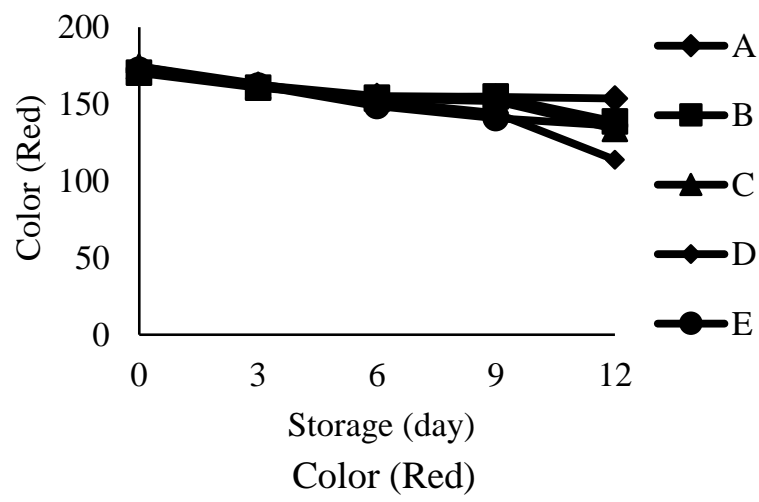

one-way analysis of variance at a significance level of $p<0.05$ and differences in the mean values were determined by Duncan's test, using SPSS Statistics 16 software.

\section{RESULTS AND DISCUSSION}

\section{Physical analysis}

A fresh strawberry should be firm to touch and bright red. This condition can be analyzed by evaluating the changes in weight loss, firmness and color of strawberry. Weight loss was induced by water loss, followed by the softens of fruit flesh and color degradation.

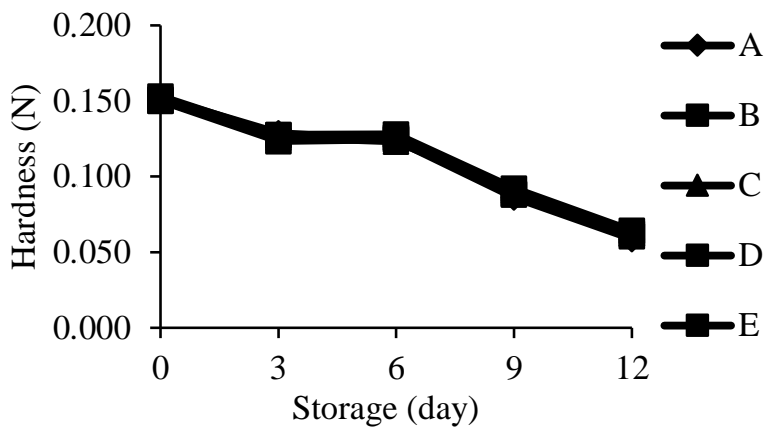

Physical parameters (Hardness)

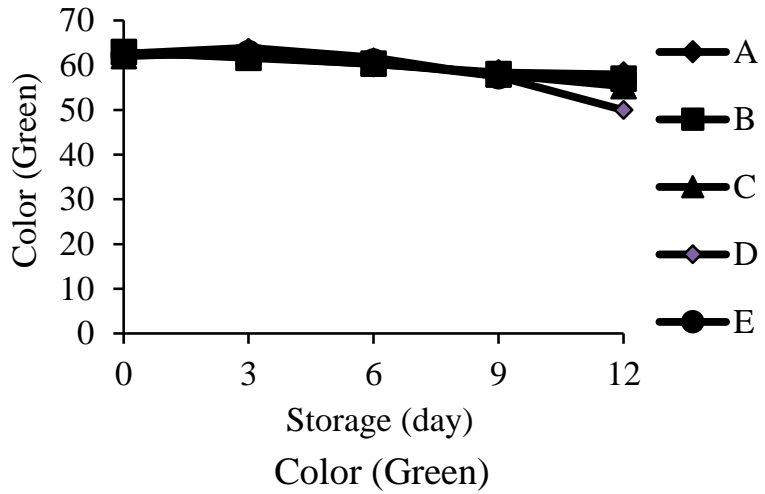

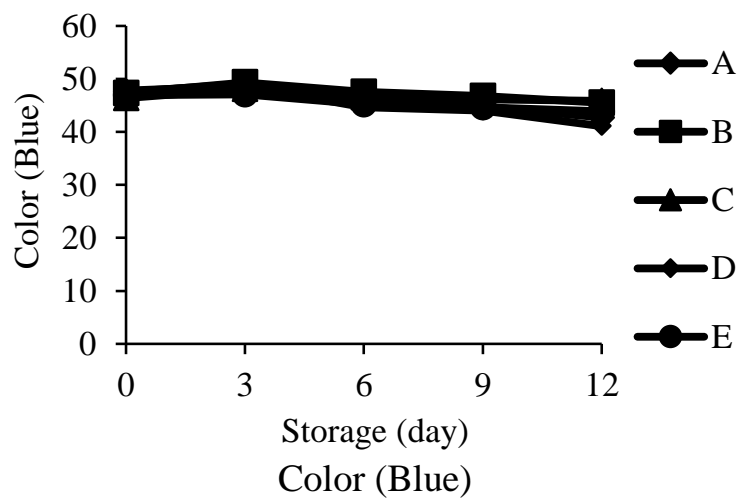

Figure 1. Effect of active paper packaging containing oleoresin extracted from the solid waste of pressed Curcuma xanthorrhiza Roxb. placement methods on the physical properties of strawberries during refrigerated storage 
Weight loss

Weight loss increased significantly $(\mathrm{p}<0.05)$ in all treatments with prolonged storage (Figure 1). Weight loss during fruit storage is due to transpiration, which releases water from the fruit and respiration, which involves the degradation of organic components (carbohydrates, fats and proteins) to produce energy. This results in the release of water and $\mathrm{CO}_{2}$ is the reduction of weight of the fruit (Novita et al., 2012).

Compared to control, active paper treatments (B-E) significantly reduced the weight loss of the strawberries until the $6^{\text {th }}$ day of storage. According to Echegoyen and Nerín (2015), the use of a larger surface area in active paper applications may decrease oxygen levels where the perforations are covered and increase exposure to essential oils. On the $9^{\text {th }}$ and $12^{\text {th }}$ days of storage, no significant differences were noted in weight loss values between strawberries in the control group and those maintained in active paper packaging. This may have resulted from the weakening of the active paper barrier during storage. The low barrier properties of paper make it not suitable for cold storage (Opara and Mditshwa, 2013).

\section{Hardness}

Fruit hardness decreased significantly $(\mathrm{p}<$ 0.05 ) during storage in all treatments. Softening of strawberries is caused by the loss of cell wall materials, as well as the presence of polygalacturonase, which solubilizes and degrades cell wall polyuronides (Ali et al., 2011). Deterioration of the cell wall structure in fruits can also resulted from the enzymatic hydrolysis of pectin and the polysaccharide matrix (Espitia et al., 2012).

Active paper packaging had no significant effect on strawberry fruit hardness (Figure 1). According to Nasution et al. (2012), fruit hardness depends on the physical condition of the fruit, i.e., wilting, wrinkles, or soft rot, which lower fruit hardness values. Wilting and wrinkles are caused by the loss of water. Nasution et al. (2012) reported that reduced water content decreases turgor pressure, which decreases the hardness of the fruit. Soft rotting on strawberries is caused by microbes such as E. carotovora, P. marginalis, bacteria from Weeksella genus (Yuliasari et al., 2015), $R$. stolonifer and M. piriformis (Siefkes-Boer et al., 2009).

\section{Color}

The color of strawberries did not significantly decrease during storage in all treatments (Figure 1). According to Nadim et al. (2015), with longer storage, the fruit becomes redder and darker. The main pigment that determines the color of strawberries is anthocyanin (Geransayeh et al., 2015), which can be damaged by heat. Light also plays a role in the anthocyanin-degradation rate; therefore, strawberries must be stored in the dark at a cold temperature (Samber et al., 2013). Significant decreases in red color were not observed after proper storage of the strawberries at $10 \pm 2^{\circ} \mathrm{C}$ in the dark.

\section{Chemical analysis}

Strawberry is one of acidic fruits that contain various organic acids so the changes in chemical content such as vitamin $\mathrm{C}$, pH, TTA during storage need to be investigated. Besides, TSS is related with fruit maturity and respiration rate.

\section{$\mathrm{pH}$, TTA and total soluble solids}

Figure 2 shows the change of $\mathrm{pH}$ and TTA content, respectively, of strawberries stored with each treatment. The results showed that $\mathrm{pH}$ values significantly increased and TTA significantly decreased (both $\mathrm{p}<0.05$ ) during storage with all treatments; different treatments, however, did not display significantly different changes in $\mathrm{pH}$ or total acids at the end of storage period. Organic acids are used as an energy source for respiration and therefore, their levels tend to decrease with prolonged storage (Syafutri et al., 1970). Changes in the TTA content can also be influenced by fruit ripening; young fruits are high in acids, which levels decrease during ripening and rise again once the fruit is overripe (Novianty, 2008). The decreased total acid content increases the $\mathrm{pH}$ value. Figure 2 also shows the changes in total soluble solids in the strawberries during storage. Soluble solid contents decreased significantly ( $p$ $<0.05$ ) with all treatments during storage. This is also due to the fruit respiration process, as sugars are used as substrates (Johansyah et al., 2014). Novita et al. (2012) also noted that fruit respiration converts sugar to pyruvic acid, producing $\mathrm{CO}_{2}$ and water. Different treatments did not have significant effects on the total soluble solids detected at the end of the storage. Taken together, the results indicated that there were no significant differences in $\mathrm{pH}$, TTA and total soluble solids at the end of storage between 
strawberries in the control group and those subjected to active paper packaging, possibly due

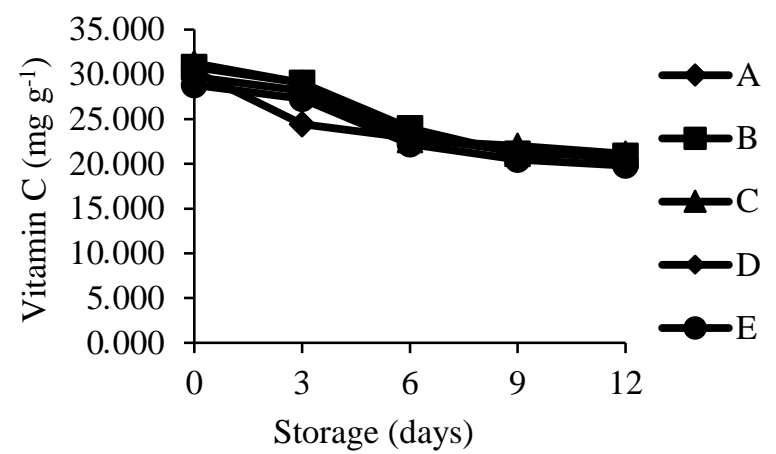

Chemical parameters (Vitamin C)

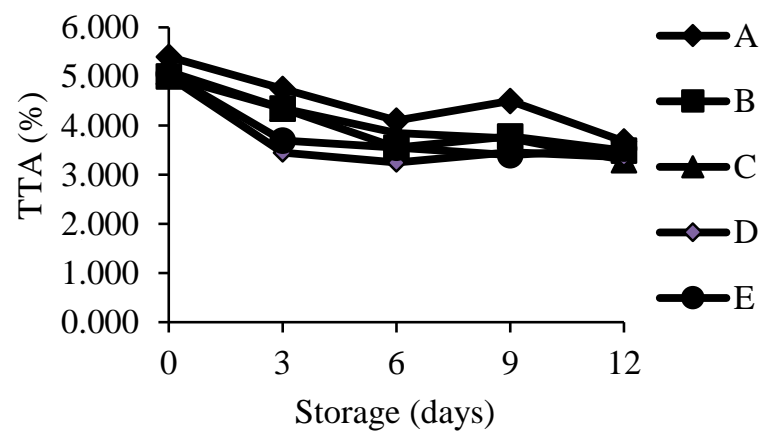

Chemical parameters (Total titratable acidity)

Figure 2. Effect of active paper packaging containing oleoresin extracted from the solid waste of pressed Curcuma xanthorrhiza Roxb. placement methods on the chemical properties of strawberries during refrigerated storage

\section{Vitamin C}

Vitamin $\mathrm{C}$ levels decreased during storage in all treatments, due to oxidation (Winarno, 2008) and at the end of storage, there were no significant differences among the treatment variations (Figure 2). However, control strawberries displayed a greater decrease in vitamin $\mathrm{C}$ content than strawberries with active paper packaging (Figure 2).

\section{Microbial analysis}

During storage, strawberries are susceptible to microbial damage which is caused by mold and bacteria. Due to Regulation E.C. (No. 2073/2005), the end of the shelf-life from the microbiological point of view, is set at $6 \log$ $\mathrm{CFU} \mathrm{g}^{-1}$ for total aerobic count mesophiles or TPC values (Nogales-Delgado et al., 2013).

Figure 3 showed that the total microbial content on the strawberries increased significantly $(\mathrm{p}<0.05)$ during storage for all treatments. The initial TPC values were 3.294-3.648 $\log 10 \mathrm{CFU} \mathrm{mL} \mathrm{m}^{-1}$. At the end of storage (day 12), to weakening of the active paper barrier during storage.

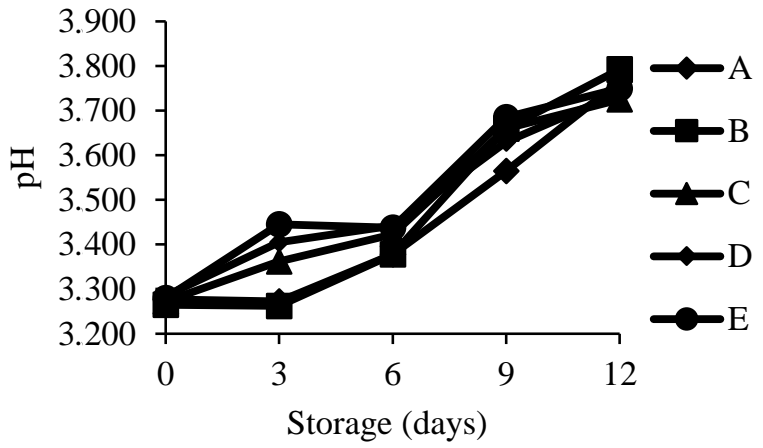

Chemical parameters $(\mathrm{pH})$

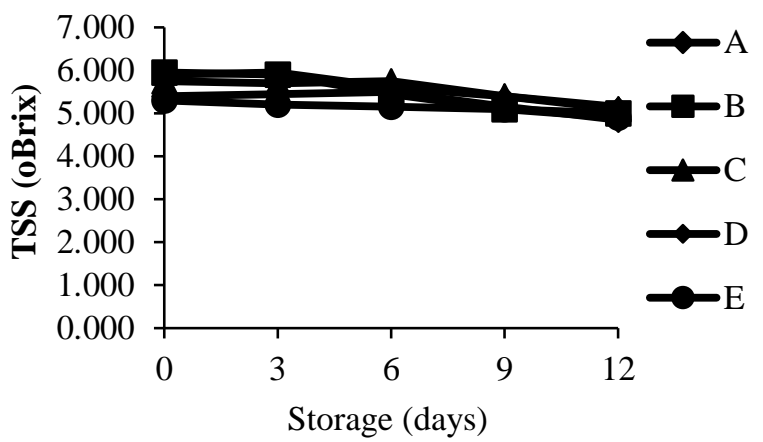

Chemical parameters (Total suspended solid) the TPC values for treatments A (control) and $\mathrm{B}$ (bottom) were higher than the maximum acceptable limit of $6 \log 10 \mathrm{CFU} \mathrm{g}{ }^{-1}$ (NogalesDelgado et al., 2013). However, the TPC values for treatments C (bottom and wall), D (envelope) and $\mathrm{E}$ (cut into pieces) remained below this limit. These results indicated that a larger surface area of active paper in contact with the strawberries provided better protection against microbes. Echegoyen and Nerín (2015) suggested that the use of the larger surface area in active paper applications decreases oxygen availability and increases exposure to essential oils.

The ability of the active paper packaging to inhibit microbiological growth is attributed to the presence of curcuma compound (curcumin and xanthorrhizol) and chitosan (Atmaka et al., 2016). Curcumin is a phenol-derived compound (Setyowati and Suryani, 2013) and xanthorrhizol contains phenolic groups on a bisabolene skeleton (Jantan et al., 2012). The antimicrobial mode act of phenol compounds is by hydrogen 
bonding with cell membrane proteins, disrupting membrane permeability and causing cell death (Dermawaty, 2015). Damaged cell membranes also cause important components such as proteins and nucleic acids to leak out of the cell, resulting in growth inhibition (Atmaka et al., 2016). Chitosan is a positive polycation that can inhibit molds and bacteria (Pebriani et al., 2012).

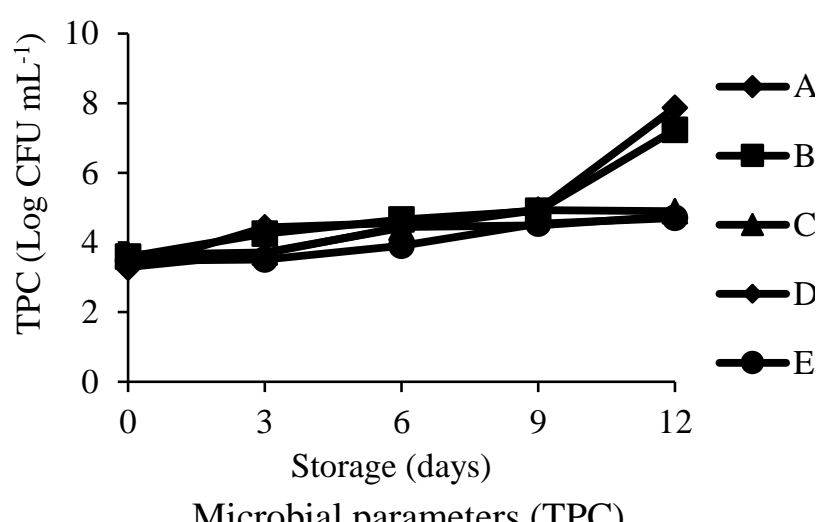

Figure 3. Effect of active paper packaging containing oleoresin extracted from the solid waste of pressed Curcuma xanthorrhiza Roxb. placement methods on the microbiological properties of strawberries during refrigerated storage

\section{CONCLUSIONS}

The results indicated that different placement methods of active paper had no significant effect on the physical and chemical qualities, but they did affect the microbiological quality of strawberries. After 12 days, the TPC values of control and B samples were higher than the maximum acceptable limit; while the others remained below the limit. These indicated that larger surface area of active paper that had contact with the strawberries provided better protection against spoilage by microbes. Due to microbial properties, $\mathrm{C}, \mathrm{D}$ and $\mathrm{E}$ treatments maintained the strawberry quality for up to 12 days, compared with 9 days by control and B treatments.

\section{ACKNOWLEDGEMENT}

This work was financially supported by research project PNBP Universitas Sebelas Maret 2017.

\section{REFERENCES}

Adipratama, D. N. (2009). Pengaruh ekstrak etanol temulawak (Curcuma xanthorrhiza Roxb.) terhadap jumlah total dan diferensiasi leukosit pada ayam petelur (gallus gallus) strain isa brown [Undergraduate Theses]. Bogor: Department of Agronomy and Horticulture, Faculty of Agriculture, IPB
University. Retrieved from https://repository. ipb.ac.id/handle/123456789/24465

Ali, A., Abrar, M., Sultan, M. T., Din, A., \& Niaz, B. (2011). Post-harvest physicochemical changes in full ripe strawberries during cold storage. Journal of Animal \& Plant Sciences, 21(1), 38-41. Retrieved from http://thejaps. org.pk/docs/21(1)2011/POST-HARVEST.pdf

AOAC. (1995). Official methods of analysis. In Association of Official Analytical Chemists. Arlington, USA: AOAC International

Atmaka, W., Manuhara, G. J., Destiana, N., Kawiji, K., Khasanah, L. U., \& Utami, R. (2016). Karakterisasi pengemas kertas aktif dengan penambahan oleoresin dari ampas pengepresan rimpang temulawak (Curcuma xanthorrhiza Roxb). Reaktor, 16(1), 32-40. https://doi.org/10.14710/reaktor.16.1.32-40

BPS - Statistics Indonesia. (2020). Production of Fruits 2011. Retrieved from https://www. bps.go.id/indicator/55/62/9/produksi-tanaman -buah-buahan.html

Brody, A., Bugusu, B., Han, J. H., Sand, C. K., \& Mchugh, T. H. (2008). Scientific status summary, Innovative food packaging solutions. Journal of Food Science, 73(8), R107-R116. https://doi.org/10.1111/j.1750-3 841.2008.00933.x

Dermawaty, D. E. (2015). Potential extract 
curcuma (Curcuma xanthorrizal Roxb) as antibacterials. Medical Journal of Lampung University, 4(1), 5-11. Retrieved from https://juke.kedokteran.unila.ac.id/index.php/ majority/article/view/494

Diastuti, H., Asnani, A. \& Chasani, M. (2019). Antifungal activity of Curcuma xanthorrhiza and Curcuma soloensis extracts and fractions. IOP Conference Series: Materials Science and Engineering, 509, 012047. https://doi.org/ 10.1088/1757-899X/509/1/012047

Echegoyen, Y., \& Nerín, C. (2015). Performance of an active paper based on cinnamon essential oil in mushrooms quality. Food Chemistry, 170, 30-36. https://doi.org/10.1016/j.foodch em.2014.08.032

Espitia P. J. P., Soares, N. dF. F., Botti, L. C. M., Melo, N. R., Pereira, O. L., \& Silva, W. A. (2012). Assessment of the efficiency of essential oils in the preservation of postharvest papaya in an antimicrobial packaging system. Brazilian Journal of Food Technology, 15(4), 307-316. https://doi.org/10.1590/S1981-6723 2012005000027

FAO. (2020). Crops production. World production quantity of strawberry during 2017-2018. Retrieved from http://www.fao. org/faostat/en/\#data/QC

Fardiaz, S. (1993). Analisis mikrobiologi pangan. Jakarta: Raja Grafindo Persada.

Geransayeh, M., \& Sepahvand, S., Abdossi, V., \& Nezhad, R. A. (2015). Effect of thymol treatment on decay, postharvest life and quality of strawberry (Fragaria ananassa) Fruit cv. 'Gaviota'. International Journal of Agronomy and Agricultural Research (IJAAR), 6(4), 151-162. Retrieved from https: //www.researchgate.net/publication/27619877 5_Effect_of_Thymol_Treatment_on_Decay_ Postharvest_life_and_Quality_of_Strawberry _Fragaria_ananassa_Fruit_cv_'Gaviota'

Jantan, I., Saputri, F. C., Qaisar, M. N., \& Buang, F. (2012). Correlation between chemical composition of Curcuma domestica and Curcuma xanthorrhiza and their antioxidant effect on human low-density lipoprotein oxidation. Evidence-Based Complementary and Alternative Medicine, 2012, 438356. https://doi.org/10.1155/2012/438356
Johansyah, A., Prihastanti, E., \& Kusdiyantini, E. (2014). Pengaruh plastik pengemas low density polyethylene (LDPE), high density polyethylene (HDPE) dan polipropilen (PP) terhadap penundaan kematangan buah tomat (Lycopersicon esculentum.Mill). Buletin Anatomi dan Fisiologi dh Sellula, 22(1), 4657. https://doi.org/10.14710/baf.v22i1.7808

Kikulwe, E. M., Okurut, S., Ajambo, S., Nowakunda, K., Stoian, D., \& Naziri, D. (2018). Postharvest losses and their determinants: A challenge to creating a sustainable cooking banana value chain in Uganda. Sustainability, 10(7), 2381. https:// doi.org/10.3390/su10072381

Kusuma, C. J. (2016). Aplikasi pengemas kertas aktif dengan penambahan oleoresin limbah destilasi kulit batang kayu manis (Cinnamomum burmanii) terhadap kualitas buah naga super merah (Hylocereus costaricensis) selama penyimpanan [Thesis]. Surakarta: Program Studi Ilmu dan Teknologi Pangan, Fakultas Pertanian, Universitas Sebelas Maret. Retrieved from https://eprints. uns.ac.id/30993/

Lee, L. Y., Shim, J.-S., Rukayadi, Y., \& Hwang, J.-K. (2008). Antibacterial activity of xanthorrhizol isolated from Curcuma xanthorrhiza Roxb. against foodborne pathogens. Journal of Food Protection, 71(9), 1926-1930. https://doi.org/10.4315/0362-028 $\mathrm{x}-71.9 .1926$

Manuhara, G. J., Khasanah, L. U., \& Utami, R. (2016). Changes in grammage, tearing resistance, and water vapor transmission rate of active paper incorporated with cinnamaldehyde during storage at various temperatures. IOP Conference Series: Materials Science and Engineering, 107, 012031. https://doi.org/10.1088/1757-899X/1 $07 / 1 / 012031$

Nadim, Z., Ahmadi, E., Sarikhani, H., \& Amiri Chayjan, R. (2015). Effect of methylcellulosebased edible coating on strawberry fruit's quality maintenance during storage. Journal of Food Processing and Preservation, 39(1), 8090. https://doi.org/10.1111/jfpp.12227

Nasution, I. S., Yusmanizar, Y., \& Melianda, K. (2012). Pengaruh penggunaan lapisan edibel (edible coating), kalsium klorida, dan kemasan 
plastik terhadap mutu Nanas (Ananas comosus Merr.) terolah minimal. Jurnal Teknologi dan Industri Pertanian Indonesia, 4(2), 21-27. Retrieved from http://jurnal.unsyiah.ac.id/TI $\mathrm{PI} /$ article/view/268

Nogales-Delgado S., Fernández-León A. M., Delgado-Adámez J., Hernández-Méndez M. T., \& Bohoyo-Gil, D. (2013). Effects of several sanitisers for improving quality attributes of minimally processed Fragaria vesca strawberry. Czech Journal of Food Sciences, 31(1), 49-54. https://doi.org/ 10.17221/378/2011-CJFS

Novianty, I. (2008). Analisa spektroskopi reflektans vis-nir untuk mengetahui proses pematangan buah stroberi [Undergraduate Theses]. Bogor: Department of Agronomy and Horticulture, Faculty of Agriculture, IPB University. Retrieved from https://repository. ipb.ac.id/handle/123456789/18616

Novita, M., Satriana, S., Martunis, M., Rohaya, S., \& Hasmarita, E. (2012). Pengaruh pelapisan kitosan terhadap sifat fisik dan kimia tomat segar (Lycopersicum pyriforme) pada berbagai tingkat kematangan. Jurnal Teknologi dan Industri Pertanian Indonesia, 4(3), 1-8. Retrieved from http://jurnal.unsyiah .ac.id/TIPI/article/view/736

Opara, U., \& Mditshwa, A. (2013). A review on the role of packaging in securing food system: Adding value to food products and reducing losses and waste. African Journal of Agricultural Research, 8(22), 2621-2630. Retrieved from https://academicjournals.org/ journal/AJAR/article-full-text-pdf/80C982E3 4864

Pebriani, R. H., Rilda, Y., \& Zulhajri, D. (2012). Modifikasi komposisi kitosan pada proses sintesis komposit TiO2-kitosan. Jurnal Kimia Unand, 1, 40-47. Retrieved from https:// www.e-jurnal.com/2013/10/modifikasi-komp osisi-kitosan-pada.html

Qanytah \& Ambarsari, I. (2011). Efisiensi penggunaan kemasan kardus distribusi mangga arumanis. Jurnal Litbang Pertanian, 30(1), 8-16. Retrieved from http://ejurnal. litbang.pertanian.go.id/index.php/jppp/article/ view/2512\#: :text=Efisiensi\%20muatan\%20p alet\%20untuk\%20berbagai,produsen $\% 2$ Fpen gekspor\%20mangga\%20di\%20Cirebon.
Rodríguez, A., Nerín, C., \& Batlle, R. (2008). New cinnamon-based active paper packaging against Rhizopusstolonifer food spoilage. Journal of Agricultural and Food Chemistry, 56(15), 6364-6369. https://doi.org/10.1021/ jf800699q

Samber, L. N., Semangun, H. \& Prasetyo, B. (2013). Karakteristik antosianin sebagai pewarna alami. Seminar Nasional $X$ Pendidikan Biologi FKIP UNS, 10(3), 1-4. Retrieved from https://jurnal.uns.ac.id/prosbi/ article/view/6428

Sawicka, B. (2019). Post-harvest losses of agricultural produce. In: Leal Filho W., Azul A., Brandli L., Özuyar P., Wall T. (eds) Zero Hunger. Encyclopedia of the UN Sustainable Development Goals. Cham, Switzerland: Springer. https://doi.org/10.1007/978-3-319-6 9626-3_40-1

Setyowati, A. \& Suryani, L. C. (2013). Peningkatan kadar kurkuminoid dan aktivitas antioksidan minuman instan temulawak dan kunyit. Agritech, 33(4), 363-370. Retrieved from https://jurnal.ugm.ac.id/agritech/article/ view/9530

Siefkes-Boer, H. J., Boyd-Wilson, K. S. H., Petley, M., \& Walter, M. (2009). Influence of coldstorage temperatures on strawberry leak caused by Rhizopus spp. New Zealand Plant Protection, 62, 243-249. https://doi.org/ 10.30843/nzpp.2009.62.4827

Skrovankova, S., Sumczynski, D., Mlcek, J., Jurikova, T., \& Sochor, J. (2015). Bioactive compounds and antioxidant activity in different types of berries. International Journal of Molecular Sciences, 16(10), 24673-24706. https://doi.org/10.3390/ijms16 1024673

Sudarmadji, S., Haryono, B., \& Suhardi. (2010). Analisa bahan makanan dan pertanian. Yoyakarta: Liberty Yogyakarta.

Syafutri, M. I., Pratama, F., \& Saputra, D. (1970). Physical and chemical characteristics of mangos (Mangifera indica L.) during storage with various methods of packaging. Jurnal Teknologi Dan Industri Pangan, 17(1), 1-11. https://journal.ipb.ac.id/index.php/jtip/article/ view/403

USDA. (2017). National nutrient database for 
standard reference. Retrieved from https:// ndb.nal.usda.gov/ndb/foods/show/2385?fgcd= $\&$ manu $=\&$ lfacet $=\&$ format $=\&$ count $=\& \max =5$ $0 \&$ offset $=\&$ sort $=$ default \&order $=$ asc $\&$ qlookup $=$ strawberry $\& \mathrm{ds}=$ Standard + Reference $\& \mathrm{q}=\&$ $\mathrm{qp}=\& \mathrm{qa}=\& \mathrm{qn}=\& \mathrm{q}=\&$ ing $=$.

Vanit, S., Suppakul, P., \& Jinkarn, T. (2010). Antimicrobial effects of coating solution containing clove oil and hydrophobic starch for coating paperboard. Asian Journal of Food and Agro-Industry, 3(02), 204-212. Retrieved from http://www.ajofai.info/Abstract/Antimic robial $\% 20$ effects $\% 20$ of $\% 20$ coating $\% 20$ soluti on $\% 20$ containing $\% 20$ clove $\% 20$ oil $\% 20$ and $\% 2$ 0hydrophobic\%20starch\%20for\%20coating\% 20paperboard.pdf

Wiastuti, T., Khasanah, L. U., Kawiji, W. A., Manuhara, G. J., \& Utami, R. (2016). Characterization of active paper packaging incorporated with ginger pulp oleoresin. IOP Conference Series: Materials Science and
Engineering, 107, 12057. https://doi.org/10. 1088/1757-899x/107/1/012057

Wibowo, H. (2003). Penetapan kadar kurkumin, minyak atsiri dan pati ampas temulawak (Curcuma xanthorrhiza Roxb.) limbah pabrik jamu IBOE dalam pemanfaatannya sebagai campuran makanan ternak ayam pedaging [Undergraduate thesis]. Surabaya: Department of Pharmacy, Faculty of Pharmacy, University of Surabaya. Retrieved from http://repository.ubaya.ac.id/3960/

Winarno, F. G. (2008). Kimia pangan dan gizi. Jakarta: Gramedia Pustaka Utama.

Yuliasari, M. M., Kawuri, R., \& Proborini, M. W. (2015). Isolasi dan identifikasi bakteri penyebab penyakit busuk lunak pada buah stroberi (Fragaria x ananassa). Metamorfosa: Journal of Biological Sciences, 2(1), 23-28. Retrieved from https://ojs.unud.ac.id/index. php/metamorfosa/article/view/14883 